\title{
Aspirin ingestion and perforated peptic ulcer
}

\author{
J. M. DUGGAN
}

From the Royal Newcastle Hospital, Newcastle, NSW, Australia

SUMMARY The results of a prospective inquiry into the aspirin taking habits of a consecutive series of 118 patients admitted to a large general hospital with acute perforation of peptic ulcer are presented. The series shows considerable increase in the proportion of females to males and of ulcers of the stomach compared to pyloro-duodenal perforations in contrast to British experience. Forty-five per cent of males and $75 \%$ of females were accustomed to taking at least two doses of an aspirin preparation weekly and most of the women took at least two doses daily. There was a highly significant association of heavy aspirin intake with ulcers of the stomach. The data support the theory that aspirin abuse is a cause of chronic gastric ulcer. It also supports the hypothesis that aspirin is the environmental factor responsible for the epidemic of gastric ulcers in middle-aged women in eastern Australia.

There is a growing awareness of the role of aspirin in the production of gastric lesions, both acute and chronic. In eastern Australia this has been linked with a high incidence of chronic gastric ulcer in persons accustomed to taking large quantities of proprietary APC powders containing aspirin, phenacetin or paracetamol, and caffeine. The present study reports a prospective investigation of the association of perforated peptic ulcer and aspirin abuse.

\section{Case Material and Methods}

For the four-year period beginning 1 July 1962 the writer attempted to interview all patients admitted to the Royal Newcastle Hospital with acute perforated peptic ulcer. In some cases, where the diagnosis was not made during life or where the patient was not able to be seen, the data are lacking. The Royal Newcastle Hospital is a large general hospital serving an industrial community of some 333000 people and it is considered that no case selection occurred.

\section{Definitions}

'Aspirin' here refers to any preparation containing aspirin whether alone or in combination. 'Heavy aspirin' refers to those patients admitting taking at least two doses daily for at least six months before admission. Those taking less but at least two doses

Received for publication 5 June 1972. weekly for a similar period were classed as 'regular' aspirin takers. Those taking none or lesser quantities were classified as 'no aspirin'. 'Aspirin before' refers to those patients who, not being accustomed to taking aspirin regularly, took some within 48 hours of the ulcer perforation. Prepyloric ulcer was diagnosed if the ulcer was between the pyloric ring and antrum and gastric if elsewhere in the stomach. No attempt was made to distinguish pyloric and duodenal ulcers, or acute from chronic ulcers.

\section{Results}

There were 118 patients admitted with perforated peptic ulcer during the period of study (Table I), comprising 90 males and 28 females. Pyloro-duo-

\begin{tabular}{|c|c|c|c|c|c|c|}
\hline & \multicolumn{6}{|c|}{ Site of Ulcer } \\
\hline & $\begin{array}{l}\text { Duodenal } \\
\text { and } \\
\text { Pyloric }\end{array}$ & $\begin{array}{l}\text { Pre- } \\
\text { pyloric }\end{array}$ & Gastric & Unknown & Stomal & Total \\
\hline $\begin{array}{l}\text { Males } \\
\text { Females }\end{array}$ & $\begin{array}{l}54 \\
11\end{array}$ & $\begin{array}{r}17 \\
3\end{array}$ & $\begin{array}{l}14 \\
13\end{array}$ & $\begin{array}{l}4 \\
1\end{array}$ & 1 & $\begin{array}{l}90 \\
28\end{array}$ \\
\hline Total & 65 & 20 & 27 & 5 & 1 & 118 \\
\hline
\end{tabular}

Table I The site of perforated peptic ulcer and sex incidence

denal perforations were present in only $55 \%$ of patients. In $40 \%$ the perforations were gastric with nearly half of these occurring in the prepyloric region. In five patients the site of perforation was unknown; the patients were either treated con- 
servatively and recovered without adequate subsequent radiological investigation or died without necropsy. The high proportion of females in the series $(24 \%)$ is noteworthy. Furthermore gastric and prepyloric ulcers comprised $57 \%$ of the total in women. In males prepyloric ulcers outnumber ulcers in the rest of the stomach and constitute $19 \%$ of all ulcers. In 95 patients there was adequate information concerning the previous aspirin intake (Table II). Only three patients were noted to have taken aspirin before the perforation not being accustomed to taking it regularly. Among men, $45 \%$ took no aspirin at all whereas $28 \%$ admitted a heavy intake. In women, the situation was reversed; $25 \%$ denied aspirin use whilst $62.5 \%$ of those with adequate data admitted a heavy intake and another $12.5 \%$ took aspirin regularly.

\begin{tabular}{|c|c|c|c|c|c|c|}
\hline & $\begin{array}{l}\text { Before } \\
\text { Perforation }\end{array}$ & $\begin{array}{l}\text { Regular } \\
\text { Intake }\end{array}$ & $\begin{array}{l}\text { Hea } \\
\text { Inta }\end{array}$ & Occasional & Unknown & None \\
\hline $\begin{array}{l}\text { Males } \\
\text { Females }\end{array}$ & 3 & $\begin{array}{r}10 \\
3\end{array}$ & $\begin{array}{l}21 \\
15\end{array}$ & 5 & $\begin{array}{r}19 \\
4\end{array}$ & $\begin{array}{r}32 \\
6\end{array}$ \\
\hline Total & 3 & 13 & 36 & 5 & 23 & 38 \\
\hline
\end{tabular}

Table II Previous aspirin intake before perforation

For the largest group, those males taking no aspirin, pyloro-duodenal ulcers outnumbered prepyloric and gastric ulcers by 3 to 1 , a ratio lower than obtained in most parts of the world. For those with a regular aspirin intake, the ratio falls to $5: 3$. By contrast, in the group with a heavy intake of aspirin, the major group comprises prepyloric ulcer. In females the numbers are low but similar trends are present. Only five took no aspirin and four of these had pyloro-duodenal ulcers. Among the heavy takers of aspirin there were again four pyloroduodenal ulcers but these were outnumbered by eight gastric and three prepyloric ulcers.

\section{Discussion}

In 1961 Douglas and Johnston from Queensland reported that many of their patients with chronic gastric ulcers suffered from chronic headaches for which the patients took aspirin. They reported 78 inpatients with gastric ulcer of whom 57 were aspirin takers and they estimated that their ulcer patients took seven times as much aspirin as the normal population. At this time the writer was engaged in a review of a large series of patients with gastrointestinal haemorrhage (Duggan, 1972) and it was becoming evident that an association of gastric ulcer and aspirin abuse existed. The present study was then initiated in 1962 as it was felt that perforation of a peptic ulcer is a dramatic event leading to admission to hospital and almost always to unequivocal localization of the ulcer. By the time of publication of the first two years' data (Duggan, 1965), Billington, in a series of papers, had drawn attention to an epidemic of gastric ulcer in young and middle-aged females in eastern Australia (Billington, 1960a, b, 1963, 1965). He deduced that the cause was an environmental one, which had begun to operate during the last war. Although the conventional view at that time (Shay and Sun, 1963) was that aspirin had no association with gastric ulcer, our preliminary results suggested that aspirin abuse was associated with perforated gastric ulcer. Furthermore the data raised the possibility that aspirin was the environmental agent proposed by Billington.

Since then it has become clear that aspirin abuse, principally in the form of proprietary powders containing aspirin, phenacetin, or paracetamol and caffeine (APC powders), is widespread in eastern Australia (Lavan, Benson, Gatenby, and Posen, 1966; Purnell and Burry, 1967; Gillies, Skyring, and Livingstone, 1972). Aspirin abuse is associated with chronic gastric ulcer, particularly in females (Gillies and Skyring, 1968; Chapman and Duggan, 1969; Alp, Hislop, and Kerr Grant, 1970), with bleeding gastric ulcer (Duggan, 1970), and with analgesic nephropathy in association with gastric ulcer (Dawborn, Fairley, Kincaid-Smith, and King, 1966; Gault, Rudwal, Engles, and Dossetor, 1968; Fellner and Tuttle, 1969; Duggan, 1971).

The present data strengthen the hypothesis (Duggan, 1965) that aspirin abuse is the environmental factor causing the epidemic of gastric ulcers in women in eastern Australia. There were 84 patients in whom the ulcer was in the stomach or pyloro-duodenal region and in whom the aspirin intake was known (Table III). There is a highly significant association of gastric ulcers and a heavy intake of aspirin $\left(\chi^{2}=11.9, \mathrm{P}<0.5 \%\right)$.

\begin{tabular}{lll}
\hline Aspirin Intake & \multicolumn{2}{l}{ Site of Ulcer } \\
\cline { 2 - 3 } & Duodenal and Pyloric & Gastric and Prepyloric \\
\hline Nil & 28 & 9 \\
Regular & 6 & 6 \\
Heavy & 12 & 23 \\
\hline
\end{tabular}

Table III Site of ulcer and aspirin intake

Hennessy (1969) from the same hospital has shown that there has been a significant increase in admissions for perforated gastric ulcer in women in a 21-year period to 1964 . The present survey shows that there is an excess of females and of gastric ulcers compared with results in large surveys in Britain (Table IV). However, the differences between the British and the Newcastle (NSW) figures virtually 


\begin{tabular}{|c|c|c|c|c|c|c|}
\hline \multicolumn{2}{|c|}{ Site and Sex Ratio } & \multirow{2}{*}{$\begin{array}{l}\text { N.E. Scotland } \\
(\text { Weir, 1960) }\end{array}$} & \multirow{2}{*}{$\begin{array}{l}\text { England and Wales } \\
\text { (Johnson, 1962) }\end{array}$} & \multicolumn{3}{|c|}{ Newcastle N.S.W. (Present Series) } \\
\hline & & & & Total Series & No Aspirin & Heavy Aspirin \\
\hline $\begin{array}{l}\text { All ulcers } \\
\text { Gastric ulcer } \\
\text { Duodenal ulcer } \\
\text { Both sexes } \\
\text { Male } \\
\text { Female }\end{array}$ & $\begin{array}{l}\text { M : F } \\
M: F \\
M: F \\
\text { DU: GU } \\
\text { DU: GU } \\
\text { DU: GU }\end{array}$ & $\begin{aligned} 8: 1 \\
2: 1 \\
9: 1 \\
17 \cdot 5: 1 \\
25: 1 \\
4 \cdot 5: 1\end{aligned}$ & $\begin{array}{r}6: 1 \\
4: 1 \\
7 \cdot 5: 1 \\
2 \cdot 5: 1 \\
2 \cdot 5: 1 \\
1 \cdot 5: 1\end{array}$ & $\begin{array}{r}3: 1 \\
2: 1 \\
5: 1 \\
1 \cdot 4: 1 \\
1 \cdot 7: 1 \\
0 \cdot 7: 1\end{array}$ & $\begin{array}{r}5 \cdot 3: 1 \\
7: 1 \\
5 \cdot 3: 1 \\
3: 1 \\
3: 1 \\
4: 1\end{array}$ & $\begin{array}{r}1 \cdot 4: 1 \\
1: 2 \\
2: 1 \\
1: 2 \\
1: 2 \\
1: 3\end{array}$ \\
\hline
\end{tabular}

Table IV Comparison of site and sex ratios in British and present series

disappear when only those taking no aspirin are considered. Whilst the evidence linking aspirin abuse and gastric ulcer in this community is strong, there is increasing evidence that aspirin containing analgesic preparations is abused in many parts of the world. Analgesic nephropathy has been recognized in Europe and Scandinavia for two decades. One might expect that aspirin-associated gastric ulcer would likewise be found. The abundant evidence from Britain and America that aspirin produces gastric bleeding (Langman, 1970) reinforces this view.

\section{References}

Alp, M. H., Hislop, I. G., and Kerr, Grant, A. (1970). Gastric ulcer in South Australia 1954-1963. I. Epidemiologica factors. Med. J. Aust., 2, 1128-1132.

Billington, B. P. (1960a). Gastric ulcer: age, sex, and a curious retrogression, Aust. Ann. Med., 9, 111-121.

Billington, B. P. (1960b). The Australian gastric ulcer change: further observations. Med. J. Aust., 2, 19-20.

Billington, B. P. (1963). The Australian gastric ulcer change: interstate variations. Aust. Ann. Med., 12, 153-159.

Billington, B. P. (1965). Observations from New South Wales on the changing incidence of gastric ulcer in Australia. Gut, 6, 121133.

Chapman, B. L., and Duggan, J. M. (1969). Aspirin and uncomplicated peptic ulcer. Gut, 10, 443-450.

Dawborn, J. K., Fairley, K. F., Kincaid-Smith, P., and King, W. E. (1966). The association of peptic ulceration, chronic renal disease, and analgesic abuse. Quart. J. Med., N.S., 35, 69-83.

Douglas, R. A., and Johnston, E. D. (1961). Aspirin and chronic gastric ulcer. Med. J. Aust., 2, 893-897.
Duggan, J. M. (1965). The relationship between perforated peptic ulcer and aspirin ingestion. Med. J. Aust., 2, 659-662.

Duggan, J. M. (1970). Gastrointestinal haemorrhage, Gastric ulcer and aspirin. Aust. Ann. Med., 19, 135-138.

Duggan, J. M. (1971). The analgesic syndrome. Aust. N.Z. J. Med., 1, 281.

Duggan, J. M. (1972). Acute gastro-intestinal haemorrhage: prognostic factors on a conservative regime. Med. J. Aust., 2, 187-193.

Fellner, S. K., and Tuttle, E. P. (1969). The clinical syndrome of analgesic abuse. Arch. intern. Med., 124, 379-382.

Gault, M. H., Rudwal, T. C., Engles, W. D., and Dossetor, J. B., (1968). Syndrome associated with the abuse of analgesics. Ann. intern. Med., 68, 906-925.

Gillies, M., and Skyring, A. (1968). Gastric ulcer, duodenal ulcer and gastric carcinoma: a case control study of certain social and environmental factors. Med. J. Aust., 2, 1132-1136.

Gillies, M. A., Skyring, A. P., and Livingstone, E. (1972). The pattern and prevalence of aspirin ingestion as determined by interview of 2,921 inhabitants of Sydney. Med. J. Aust., 1, 974-979.

Hennessy, E. (1969). Perforated peptic ulcer: mortality and morbidity in 603 cases. Aust. N.Z. J. Surg., 38, 243-252.

Johnson, H. D. (1962). Peptic ulcer in hospital: an analysis of a $10 \%$ in-patient enquiry throughout England and Wales. Gut, 3, 106117.

Langman, M.J.S. (1970). Epidemiological evidence for the association of aspirin and acute gastrointestinal bleeding. Gut, 11, 627634.

Lavan, J. N., Benson, W. J., Gatenby, A. H., and Posen, S. (1966). The consumption of analgesics by Australian hospital patients. Med. J. Aust., 2, 694-695.

Purnell, J., and Burry, A. F. (1967). Analgesic consumption in a country town. Med. J. Aust., 2, 389-391.

Shay, H., and Sun, D. C. H. (1963). Aetiology and pathology of gastric and duodenal ulcer. In Gastroenterology, 2 nd ed., vol. 1, edited by H. L. Bockus, pp. 420-465. Saunders, Philadelphia and London.

Weir, R. D. (1960). Perforated peptic ulcer in north-east Scotland. Scot. med. J., 5, 257-264. 